\title{
Potentiated antitumor effects of the combination treatment with statins and pamidronate in vitro and in vivo
}

\author{
TADEUSZ ISSAT $^{1}$, DOMINIKA NOWIS ${ }^{1}$, MAGDALENA LEGAT ${ }^{1,2}$, MARCIN MAKOWSKI $^{1}$, \\ MARCIN P. KLEJMAN ${ }^{3}$, JAKUB URBANSKI ${ }^{3}$, JANUSZ SKIERSKI ${ }^{4}$, MIROSLAWA KORONKIEWICZ ${ }^{4}$, \\ TOMASZ STOKLOSA ${ }^{1}$, AGNIESZKA BRZEZINSKA ${ }^{5}$, JACEK BIL ${ }^{1}$, JAN GIETKA $^{1}$, \\ MAREK JAKÓBISIAK $^{1}$ and JAKUB GOLAB ${ }^{1}$
}

\begin{abstract}
${ }^{1}$ Department of Immunology, Center of Biostructure, The Medical University of Warsaw, Banacha 1a, F building, 02-097 Warsaw; ${ }^{2}$ Department of Laboratory Diagnostics and Clinical Immunology, Medical University of Warsaw, Marszalkowska 24, 00-576 Warsaw; ${ }^{3}$ Department of Molecular Biology, International Institute of Molecular and Cell Biology, ul. Ks. Trojdena 4, 02-109 Warsaw; ${ }^{4}$ Cell Biology Department, The National Institute of Public Health, 30/34 Chelmska Str., 00-725 Warsaw; ${ }^{5}$ Laboratory of Molecular Bases of Aging, Department of Biochemistry, Nencki Institute of Experimental Biology, Polish Academy of Sciences, Pasteur 3, 02-093 Warsaw, Poland
\end{abstract}

Received January 29, 2007; Accepted March 15, 2007

\begin{abstract}
The aim of the present study was to examine the potential antitumor activity of lovastatin and other statins together with pamidronate, a second generation bisphosphonate (BP), against tumor cell lines. Cytostatic/cytotoxic effects were measured using crystal violet assay. Regulation of the cell cycle and induction of apoptosis were evaluated using flow cytometry and Western blotting, migration of tumor cells was measured in a scratch wound assay and their invasiveness was measured with a Matrigel-invasion assay. Antitumor effects of the combination treatment were evaluated in a murine PANC 02 pancreatic adenocarcinoma model. Combination of pamidronate and lovastatin produced potentiated cytostatic/ cytotoxic effects against breast and pancreatic cancer cell lines. The combination was also effective in inhibition of tumor cell adhesion to collagen IV and fibronectin and interfered with migration and invasiveness of tumor cells. Neither
\end{abstract}

Correspondence to: Dr Jakub Golab, Department of Immunology, Center of Biostructure, The Medical University of Warsaw, ul. Banacha 1a, F building, 02-097 Warsaw, Poland

E-mail: jgolab@ib.amwaw.edu.pl

Abbreviations: FACS, fluorescence activated cell sorter; FPP, farnesyl pyrophosphate; FTI, farnesyltransferase inhibitor; GGPP, geranylgeranyl pyrophosphate; GGTI, geranylgeranyltransferase inhibitor; HMG-CoA, 3-hydroxy-3-methylglutaryl-coenzyme A; MTT, 3-(4,5-dimethylthiazol-2-yl)-diphenyltetrazolium bromide; $\mathrm{N}-\mathrm{BP}$, nitrogen-containing bisphosphonates; PI, propidium iodide

Key words: statins, bisphosphonates, cancer, cytostatic/cytotoxic effects, antitumor pamidronate nor lovastatin alone affected tumor growth in mice but the combination treatment resulted in retardation of tumor growth and prolongation of mouse survival. The combination of statins and pamidronate, a second generation bisphosphonate, demonstrates promising antitumor effects at doses readily achievable in patients. This combination holds promise for future clinical studies.

\section{Introduction}

Statins are competitive inhibitors of 3-hydroxy-3-methylglutaryl-coenzyme A (HMG-CoA) reductase that inhibit the synthesis of mevalonic acid, an essential precursor of isoprenoid compounds including cholesterol, dolichol, and ubiquinone as well as farnesyl and geranylgeranyl groups required for posttranslational modification of many proteins including Ras/Rho superfamily members (1). Due to their ability to lower blood cholesterol levels statins are commonly used to prevent and to treat atherosclerosis of the coronary vessels.

Statins have also been found to induce cytostatic and cytotoxic effects against tumor cells in vitro (2-6) and to exert antitumor effects in experimental tumor models $(7,8)$. Results of clinical studies revealed only modest (9) or not very encouraging (10) antitumor activity of statins. Several studies revealed that long-term use of statins is associated with diminished cancer incidence $(11,12)$ but again these observations have not been confirmed by other studies $(13,14)$ and few have even shown increased cancer incidence in statin users (15).

Bisphosphonates are analogs of endogenous pyrophosphate with a central oxygen atom replaced by a carbon atom. They are potent inhibitors of bone resorption used for the management and prevention of postmenopausal osteoporosis, corticosteroid-induced bone loss, and Paget's disease. They increase bone mass, diminish fracture risk and alleviate bone 
pain as well as bone, joint and neurological complications $(16,17)$. Due to their anti-resorptive activity they are also used in the treatment of bone metastases reducing the occurrence of pathologic fractures, bone pain and the need for radiation therapy or surgery in patients with osteolytic metastases (18-20). They are also effective in the management of hypercalcemia of malignancy $(21,22)$. All these effects translate into improved quality of life.

Nitrogen-containing bisphosphonates (N-BP) that include zoledronic acid, pamidronate or ibandronate among others have a unique mechanism of action as compared with first generation bisphosphonates in that they inhibit mevalonate pathway of cholesterol biosynthesis thereby preventing posttranslational protein prenylation $(23,24)$. Recently, preclinical studies demonstrated that N-BPs might also have direct antitumor activity (25). N-BPs inhibit proliferation and induce apoptosis of a number of human tumor cell lines in vitro, inhibit the ability of tumor cells to adhere to mineralized or unmineralized matrices and to invade extracellular matrix (25-29). In vivo studies revealed their antitumor and antimetastatic effects that might result from both direct action on tumor cells as well as from inhibition of tumor angiogenesis (27,30-32). Clinical observations seem to confirm that N-BPs inhibit the lesion progression in patients with multiple myeloma and prostate cancer and may prevent the development of new bone metastases and skeletal complications in patients with breast cancer $(33,34)$.

Accumulating evidence indicates that the antitumor effectiveness of bisphosphonates can be potentiated by chemotherapeutics, radiotherapy and antiestrogens (35-39). Despite modest antitumor activity of statins their potential use in clinical oncology evokes increasing interest. It seems that these drugs could find their place in clinical cancer therapy if combination therapies are found in which statins are shown to exert potentiated antitumor effects. Therefore, we investigated whether the combination of pamidronate and statins could produce potentiated antitumor effects.

\section{Materials and methods}

Mice. C57B16 mice, 8-12 weeks of age were used in the experiments. Breeding pairs were obtained from the Animal House of the Medical Research Centre, Polish Academy of Sciences. Mice were kept in conventional conditions with full access to food and water during experiments. All of the animal studies were performed in accordance with the guidelines approved by the Ethics Committee of the Medical University of Warsaw.

Tumor cells. The following human breast cancer cell lines: MDA-MB-361, MDA-MB-231, MCF-7 and human pancreatic cancer cell lines: PANC-1, MIA PaCa-2, all from ATCC (American Type Culture Collection, Rockville, MD, USA) were used throughout all experiments. PANC 02 murine pancreatic carcinoma cells were kindly obtained from Carsten Ziske (Rheinische Friedrich-Wilhelms-Universität, Bonn, Germany). Cells were maintained in DMEM or RPMI-1640 medium (Invitrogen, Co., Paisley, UK), supplemented with $10 \%$ heat-inactivated fetal bovine serum (FBS), antibiotics, 2-mercaptoethanol $(50 \mu \mathrm{M})$ and L-glutamine (2 mM) (all from Invitrogen, Co.), hereafter referred to as culture medium. Cells were cultured in $75-\mathrm{cm}^{2}$ tissue flask (Corning, NY, USA) at $37^{\circ} \mathrm{C}$ in a fully humidified atmosphere of $5 \% \mathrm{CO}_{2}$, and were passaged every 3-4 days after short trypsinization with trypsin/EDTA (Invitrogen, Co.).

Reagents. The following statins have been used: atorvastatin (Pfizer Pharmaceuticals, Inc., Groton, CT), cerivastatin (Bayer Corp., West Haven, CT), mevastatin (ICN Biochemicals, Costa Mesa, CA), simvastatin and lovastatin (both from Merck, Sharp \& Dohme Res. Lab., Rahway, NJ). Mevastatin and lovastatin were obtained in the inactive lactone form and were converted to the active form as described (40). Pamidronate sodium (Vipharm, Warsaw, Poland) was dissolved in water to the final stock concentration of $97.6 \mathrm{mM}$. Farnesyl pyrophosphate (FPP) and geranylgeranyl pyrophosphate (GGPP) were purchased from Sigma (St. Louis, MO, USA). Farnesyl transferase inhibitor (FTI-277) and geranylgeranyl transferase inhibitor (GGTI-298) were purchased from Calbiochem (San Diego, CA).

Tumor treatment and monitoring. For in vivo experiments exponentially growing PANC 02 cells were harvested from culture flasks and washed twice in cold-PBS (Polfa, Poland). Cells were then resuspended in PBS to a concentration of $50 \times 10^{6}$ cells $/ \mathrm{ml}$ and injected $2 \times 10^{5}$ cells in $20 \mu \mathrm{PBS}$ into the footpad of the right hind limbs of C57B16 mice. PANC 02 viability, estimated by trypan-blue staining, ranged between 95 and $97 \%$. Lovastatin was administered intraperitoneally (i.p.) at a dose of $30 \mathrm{mg} / \mathrm{kg}$ daily starting from day 7 after inoculation of tumor cells for 14 consecutive days. Control mice received an equal volume of $20 \%$ ethanol. Pamidronate was administrated i.p. at a dose of $10 \mathrm{mg} / \mathrm{kg}$ on days 7 and 14 following inoculation of tumor cells. Local tumor growth was determined as described (41) by the formula: tumor volume $\left(\mathrm{mm}^{3}\right)=($ longer diameter $) \times$ (shorter diameter $)^{2}$. Relative tumor volume was calculated as: relative tumor volume $=$ [(tumor volume)/(initial volume) $\mathrm{x} 100 \%$.

Western blotting. For analysis of protein expression cells were cultured with drugs for $48 \mathrm{~h}$. After an indicated time of culture the cells were washed with PBS and lysed with radioimmunoprecipitation assay buffer (RIPA) containing $50 \mathrm{mM}$ Tris base, $150 \mathrm{mM} \mathrm{NaCl}, 1 \% \mathrm{NP}-40,0.25 \%$ sodium deoxycholate and $1 \mathrm{mM}$ EDTA supplemented with Complete ${ }^{\circledR}$ protease inhibitor cocktail tablets (Roche Diagnostics, Mannheim, Germany). Protein concentration was measured using Bio-Rad Protein Assay (Bio-Rad, Hercules, CA, USA). Equal amounts of whole cell proteins were separated on $12.5 \%$ SDS-polyacrylamide gel, transferred onto Protran ${ }^{\circledR}$ nitrocellulose membranes (Schleicher and Schuell BioScience Inc., Keene, NH, USA), blocked with TBST [Tris-buffered saline (pH 7.4) and $0.05 \%$ Tween-20] supplemented with $5 \%$ non-fat milk and 5\% FBS. The following antibodies at 1:1000 dilution were used for the 24-h incubation: mouse monoclonal antibodies anti- $\alpha$-tubulin (Calbiochem, San Diego, CA), anti-cleaved caspase-3 (Cell Signaling Technology, Beverly, MA), anti-p21, anti-cdk2, anti-cdk6, anti-cyclin D1, anti-p27 (all from Santa Cruz). After extensive washing with TBST, the membranes were incubated for $45 \mathrm{~min}$ with 
corresponding horseradish peroxidase-coupled secondary antibodies (Jackson Immuno Research). The color reaction for horseradish peroxidase was developed using SuperSignal WestPico Trail Kit ${ }^{\circledR}$ (Pierce). The X-ray film was exposed for different periods of time depending on the kind of antibody and developed with a standard X-ray film developer. The blots were stripped between antibodies in $0.1 \mathrm{M}$ Glycine ( $\mathrm{pH} 2.5)$.

Cytostatic/cytotoxic assay. The cytostatic and/or cytotoxic effects of treatment of tumor cells were measured using crystal violet staining as described (42). Briefly, tumor cells were dispensed into 96-well plates (Nunc) at a concentration depending on the tumor line (MDA-MB-231 and PANC 02 tumor cells were seeded at $5 \times 10^{3}$ cells per well/100 $\mu 1$; MIA PaCa-2, PANC-1, and MDA-MB-361 cells were seeded at $7.5 \times 10^{3}$ cells per well/100 $\mu 1$; MCF7 tumor cells were seeded at $1 \times 10^{4}$ cells per well/100 $\mu$ l) and allowed to attach overnight. The following day all reagents were added. Then, $48 \mathrm{~h}$ after incubation with reagents the cells were rinsed with PBS and stained with $0.5 \%$ crystal violet in $30 \%$ ethanol for $10 \mathrm{~min}$ at room temperature. Plates were washed four times with tap water and the cells were lysed with $1 \%$ SDS solution. Absorbance was measured at $595 \mathrm{~nm}$ using an enzyme-linked immunosorbent assay reader (SLT Labinstrument GmbH, Salzburg, Austria), equipped with a 595-nm filter. Cytotoxicity was expressed as relative viability of tumor cells (\% of control cultures incubated with medium only) and was calculated as follows: relative viability $=\left(A_{e}-A_{b}\right) \times 100 /\left(A_{c}-A_{b}\right)$, where $A_{b}$ is the background absorbance, $A_{e}$ is experimental absorbance, and $A_{c}$ is the absorbance of untreated controls.

Cell cycle. For the cell cycle analysis tumor cells were scraped off the Petri dishes (Nunc) in chilled PBS after incubation with lovastatin or pamidronate or both reagents together for 12,24 , or $48 \mathrm{~h}$. Cells were then washed twice and fixed in $70 \%$ ethanol in PBS. Analysis of the cell cycle was performed with propidium iodide (Roche, Indianapolis, IN, USA) according to the manufacturer's protocols and analyzed using FACS Vantage (Becton-Dickinson, San Jose, CA, USA). To detect apoptosis, cells were trypsinized from the Petri dishes (Nunc) in cold-PBS, washed twice in PBS and suspended in chilled PBS.

Adhesion, migration and invasion assays. For the adhesion assay, pamidronate and/or lovastatin pretreated cells were harvested and plated at a density of $5 \times 10^{5}$ cells/well in 24-well plates coated with fibronectin or collagen IV (BectonDickinson). After a $30-\mathrm{min}$ incubation at $37^{\circ} \mathrm{C}$ in a $\mathrm{CO}_{2}$ incubator, the plates were shaken at $200 \mathrm{rpm}$ for $10-15 \mathrm{sec}, 3$ times washed with $0.1 \%$ BSA in PBS and fixed with $4 \%$ paraformaldehyde. The cells were stained with crystal violet, washed with water and photographed. Finally, the cells were lysed by addition of $1 \%$ SDS and the absorbance from quadruplicate wells was assessed using an enzyme-linked immunosorbent assay reader (SLT Labinstrument $\mathrm{GmbH}$ ).

A modified scratch-wound assay was used for the evaluation of tumor cell migration. MDA-MB-231 cells were seeded in triplicate on a 24-well plate in culture medium with lovastatin $(0.2 \mu \mathrm{M})$, pamidronate $(10 \mu \mathrm{M})$, FPP $(10 \mu \mathrm{M})$ and/or, GGPP $(10 \mu \mathrm{M})$. After $24 \mathrm{~h}$ a scratch was made across the cell layer (at $60-80 \%$ confluence) with a pipette tip. Cells were washed twice with PBS and medium with drugs was reapplied. Pictures of the same areas of the wells were taken at 0,26 , and $48 \mathrm{~h}$. The migration of the drug-treated cell population was quantified by calculating the percentage of recolonization of the wound surface over time as compared with untreated cells.

For the invasion assay a Growth Factor Reduced Matrigel Matrix (BD Biosciences, San Diego, CA, USA) was diluted to $500 \mu \mathrm{g} / \mathrm{ml}$ in PBS and $100 \mu 1$ were applied on polycarbonate filters $(6.5 \mathrm{~mm}$ of diameter, $8.0-\mu \mathrm{m}$ pore size) (Transwell, Corning Incorporated, Corning, NY, USA). Filters were allowed to dry for $24 \mathrm{~h}$ and were subsequently rehydrated with $50 \mu 1$ of serum-free DMEM containing lovastatin, pamidronate with or without FPP or GGPP at indicated concentrations for $2 \mathrm{~h}$ at $37^{\circ} \mathrm{C}$ in a humidified atmosphere. MDA-MB-231 cells $\left(4 \times 10^{5}\right)$ were seeded for $24 \mathrm{~h}$ on $6-\mathrm{cm}$ tissue culture plates in DMEM containing 10\% FBS followed by the addition of lovastatin, pamidronate, GGPP and/or FPP. After another $24 \mathrm{~h}$ cells were detached by trypsin, washed twice with PBS, resuspended in serum-free DMEM and $1 \times 10^{5}$ cells were seeded on matrigel-coated inserts. DMEM containing $10 \%$ FBS and appropriate drugs were added to lower chambers as attractant. After another $24 \mathrm{~h}$ inserts were washed with PBS, Matrigel with cells that did not migrate was removed, cells on the lower surface of filters were fixed with 95\% methanol and 5\% PBS solution and stained with DAPI. Cell nuclei at the center of the filter were counted under the fluorescence microscope. In parallel, the same amount of cells treated identically as above were seeded on a 96-well plate in DMEM containing 10\% FBS and stained with crystal violet after $24 \mathrm{~h}$ of incubation.

Gelatin zymography. MDA-MB-231 cells were treated with lovastatin $(0.2 \mu \mathrm{M})$ and/or pamidronate $(10 \mu \mathrm{M})$ for $24 \mathrm{~h}$ in DMEM containing $10 \%$ FBS. After that serum-free medium containing drugs was applied for $24 \mathrm{~h}$. Medium was collected, $10 \mu 1$ was mixed with SDS-loading buffer without $\beta$-mercaptoethanol and resolved on SDS-gel containing $1 \mathrm{mg} / \mathrm{ml}$ gelatin. Gel was incubated twice in $2.5 \%$ Triton X-100 for $15 \mathrm{~min}$, incubated for $72 \mathrm{~h}$ in $50 \mathrm{mM}$ Tris- $\mathrm{HCl} \mathrm{pH} 8.0,150 \mathrm{mM} \mathrm{NaCl}$, $10 \mathrm{mM} \mathrm{CaCl}_{2}, 1 \mu \mathrm{M} \mathrm{ZnCl}_{2}, 0.02 \%$ Brij-35, 0.02\% sodium azide at $37^{\circ} \mathrm{C}$ and stained with Coomassie.

Statistical analysis. Data were calculated using Microsoft ${ }^{\mathrm{TM}}$ Excel 98. Differences in in vitro cytotoxicity assays and tumor volume were analyzed for significance by Student's t-test. Significance was defined as a two-sided $\mathrm{P}<0.05$.

The nature of the interaction observed between pamidronate and lovastatin was analysed using the Calcusyn software (Biosoft, Cambridge, UK) which uses the CI method of Chou and Talalay (43), based on multiple drug effect equation. The constant ratio combination design was applied to assess the effect of both drugs in combination, in which dose-response curves were determined. The advantage of this method is the automatic construction of a fraction affected-CI table, graph, and calculation of dose reduction indices by the software. CIs $<1$ indicate greater than additive effects (synergism; the smaller the value, the greater the degree of synergy), CIs 
Table I. The $50 \%$ growth inhibition for pamidronate and lovastatin against human tumor cell lines. ${ }^{a}$

\begin{tabular}{lcc}
\hline Tumor cell line & $\begin{array}{c}\text { Pamidronate } \\
\text { concentration } \\
\mu \mathrm{M}\end{array}$ & $\begin{array}{c}\text { Lovastatin } \\
\text { concentration } \\
\mu \mathrm{M}\end{array}$ \\
\hline PANC 02 & 80 & 0.5 \\
PANC-1 & 20 & 10 \\
MIA PaCa-2 & 40 & 3 \\
MDA-MB-231 & 30 & $1-2$ \\
MDA-MB-361 & 120 & $0.5-1$ \\
\hline
\end{tabular}

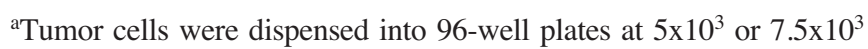
cells per well/100 $\mu \mathrm{l}$ and allowed to attach overnight. The following day serial dilutions of pamidronate or lovastatin in $100 \mu 1$ of medium were added. Then, after $48 \mathrm{~h}$ of incubation the cells were rinsed with PBS and stained with crystal violet and the absorbance was evaluated with a microplate reader.

equal to 1 indicate additivity, and CIs $>1$ indicate antagonism. The dose reduction index defines the extent of drug dose reduction possible in combination for a given degree of effect as compared with the dose of each drug alone (43).

\section{Results}

Pamidronate and lovastatin exert synergistic cytostatic/cytotoxic effects against tumor cells in vitro. We have investigated the cytostatic/cytotoxic effects exerted by pamidronate and lovastatin as well as by their combination against human tumor cell lines of pancreatic (PANC 02, PANC-1, MIA PaCa-2) and breast (MDA-MB231, MDA-MB-361, T47D) origin using crystal violet staining. Both pamidronate and lovastatin exerted a dose- and time-dependent growth inhibition in the investigated tumor cell lines. The $50 \%$ growth inhibition $\left(\mathrm{IC}_{50}\right)$ after a 48 -h incubation period was reached at pamidronate concentrations between 20 and $60 \mu \mathrm{M}$ in most of the cell lines. Only MDA-MB-361 cells were resistant to pamidronatemediated growth inhibition. For lovastatin $\mathrm{IC}_{50}$ was between 0.5 and $3 \mu \mathrm{M}$. Only PANC-1 required higher doses of lovastatin $(10 \mu \mathrm{M})$ to achieve $\mathrm{IC}_{50}$ (Table I).

The combination of pamidronate and lovastatin exerted potentiated cytostatic/cytotoxic effects against all investigated tumor cell lines. The experiments were performed with crystal violet staining and confirmed in some cell lines with MTT assay. The resulting data were elaborated with a dedicated software Calcusyn to verify potential synergistic interactions between the investigated agents using Chow and Talalay calculations. In this mathematical model, synergism can be defined when the combination index (CI) is $<1.0$ (when CI is $<0.5$ the synergism is defined as very strong). We have found that the combination of pamidronate and lovastatin was highly synergistic when both drugs were used at equipotent concentrations against PANC-1, PANC 02 and MDA-MB231 cells. A synergistic interaction was also noted for MIA PaCa-2, MDA-MB-361 cells (Fig. 1). Unexpectedly, we have observed that the combination of pamidronate and lovastatin was antagonistic when used in vitro against MCF-7 breast cancer cells (Fig. 1).

Importantly, other statins including atorvastatin, cerivastatin, mevastatin and simvastatin also significantly potentiated the cytostatic/cytotoxic effects of pamidronate in vitro against PANC 02 cells (Fig. 2).

The combination of pamidronate and lovastatin induces cell cycle arrest and apoptosis. We have selected such concentrations of pamidronate and lovastatin that were highly synergistic at Calcusyn calculations to evaluate the influence of the combination on the cell cycle and apoptosis induction in PANC 02 cells (Table II). Lovastatin used at a $0.25-\mu \mathrm{M}$ concentration had already induced G1 arrest after $24 \mathrm{~h}$ of incubation. After another $24 \mathrm{~h}, 18.47 \%$ of the cells were found in the sub-G1 fraction. Pamidronate at the concentration of $40 \mu \mathrm{M}$ did not significantly influence cell cycle distribution or apoptosis-induction in tumor cells. However, it augmented the lovastatin-induced G1 arrest after $24 \mathrm{~h}$ and significantly increased the percentage of cells in sub-G1 fraction (from 18.47 to $33.59 \%$ ) (Fig. 3A and Table II). Western blotting analysis of cell cycle regulating proteins revealed that both lovastatin and pamidronate decreased the expression of CDK2 and cyclin D1 and slightly induced the expression of $\mathrm{p} 21^{\text {Waf-1 }}$. Lovastatin was also effective in the slight induction of p27 $7^{\text {Kip-1 }}$ expression and in decreasing CDK6 expression. The combination of both drugs induced the highest expression of $\mathrm{p} 21^{\text {Waf-1}}$, completely decreased the expression of cyclin D1, and induced cleavage of caspase-3 (Fig. 3).

The cytostatic/cytotoxic effects of the combination of pamidronate and lovastatin result from inhibition of isoprenoid compound synthesis. By inhibiting HMG-CoA reductase, statins decrease synthesis of mevalonic acidderived isoprenoid derivatives thereby influencing posttranslational processing of numerous proteins, including Ras and Rho family members. Incubation of PANC 02 and MDA-MB-231 cells with mevalonic acid, farnesyl or geranylgeranyl pyrophosphate abrogated the antitumor effectiveness of the combination of pamidronate and lovastatin (Fig. 4). Interestingly, FPP was less effective than GGPP in reversing the growth-inhibitory effect of the combination treatment in MDA-MB-231 cells. To further verify the role of protein prenylation in the cytostatic/cytotoxic effects of statins used in combination with pamidronate, we combined the latter with inhibitors of protein farnesylation and geranylgeranylation. Inhibition of geranylgeranyltransferase was effective in potentiating the cytostatic/cytotoxic effects of pamidronate in both cell lines. FTI potentiated the cytostatic/cytotoxic effects of pamidronate in PANC 02 cells but was completely ineffective in doing so in MDA-MB-231 cells (Fig. 4).

The combination of pamidronate and lovastatin inhibits adhesion, migratory capacity and invasiveness of tumor cells. The influence of pamidronate and lovastatin on adhesive properties of MDA-MB-231 cells was evaluated using 24-well plates covered with basement membrane proteins fibronectin and collagen IV (Fig. 5A-F). A 24-h incubation with either drug alone did not affect adhesion of tumor cells but incubation 

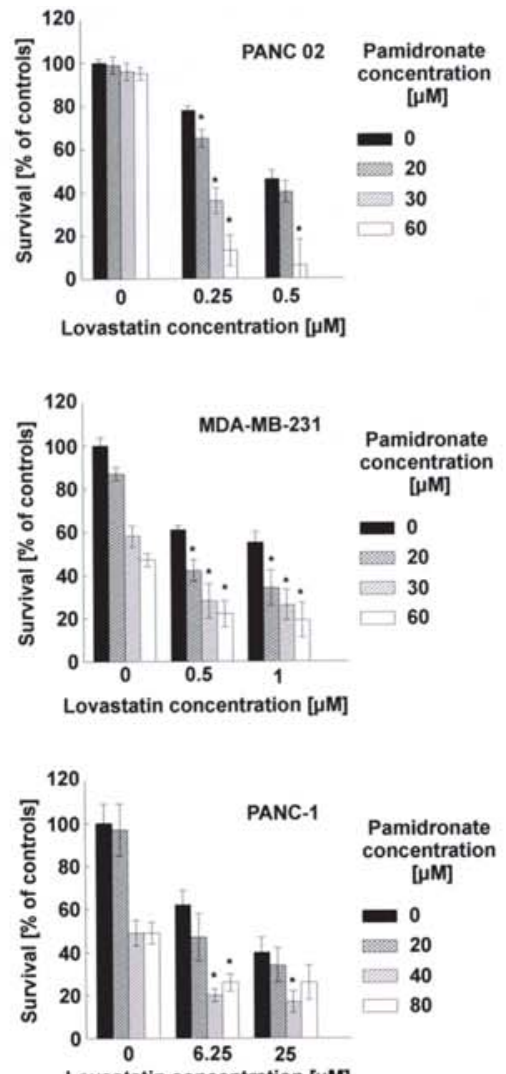

Lovastatin concentration $[\mu \mathrm{M}]$
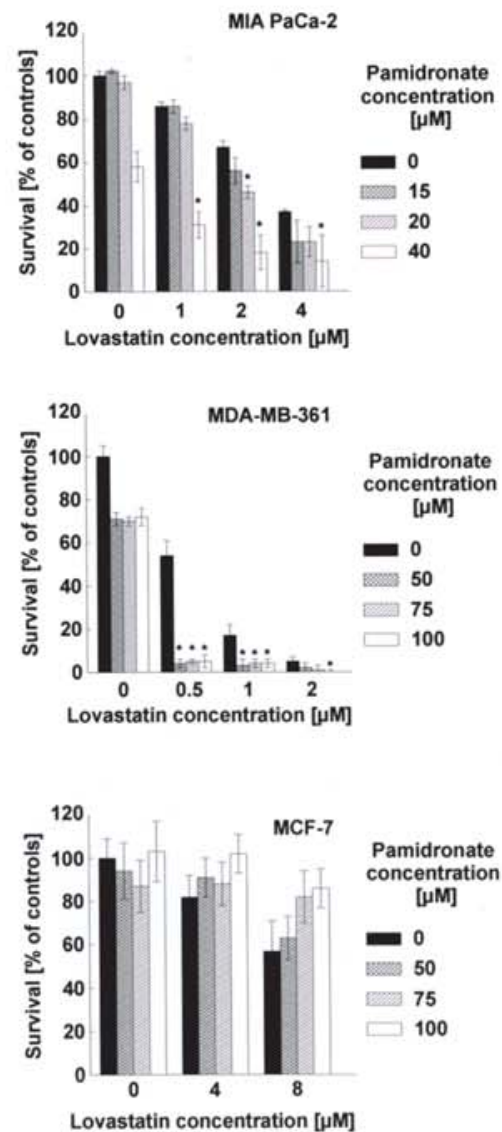
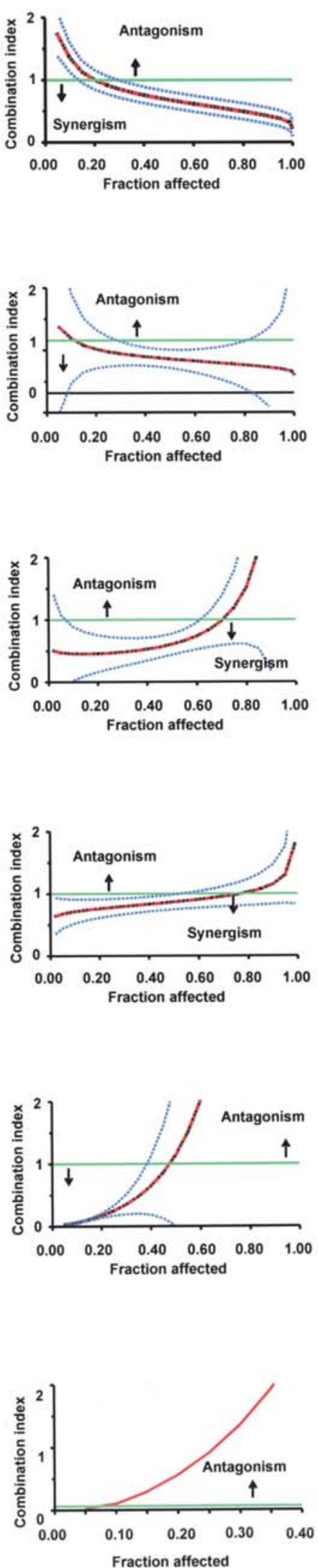

Figure 1. Potentiation of in vitro cytotoxic effects of pamidronate by lovastatin. Tumor cells of pancreatic (PANC 02, PANC-1, MIA PaCa-2) and breast cancer (MDA-MB-231, MDA-MB-361, T47-D, MCF-7) origin were dispensed into a 96-well flat-bottomed microtiter plate at a concentration of 5-10x103 cells/ $100 \mu \mathrm{l} /$ well. Cells were incubated with dilutions of pamidronate and/or lovastatin or a control Et-OH-containing medium. After $48 \mathrm{~h}$ the cytostatic/cytotoxic effects were measured using crystal violet staining and are expressed as mean survival (as compared with controls) \pm SD. Next to the graphs showing cytostatic/cytotoxic effects there are results of the Chow and Talalay analyses of the combination indices (CI) presented here as a function of inhibition of cell growth in cells exposed to pamidronate and lovastatin for $48 \mathrm{~h}$ (solid red lines) $\pm \mathrm{SD}$ (thin hyphenated line). The straight line at $\mathrm{CI}=1$ represents the additive effects of both drugs. ${ }^{*} \mathrm{P}<0.05$ (Student's t-test) as compared with controls and single agent-treated cells. 

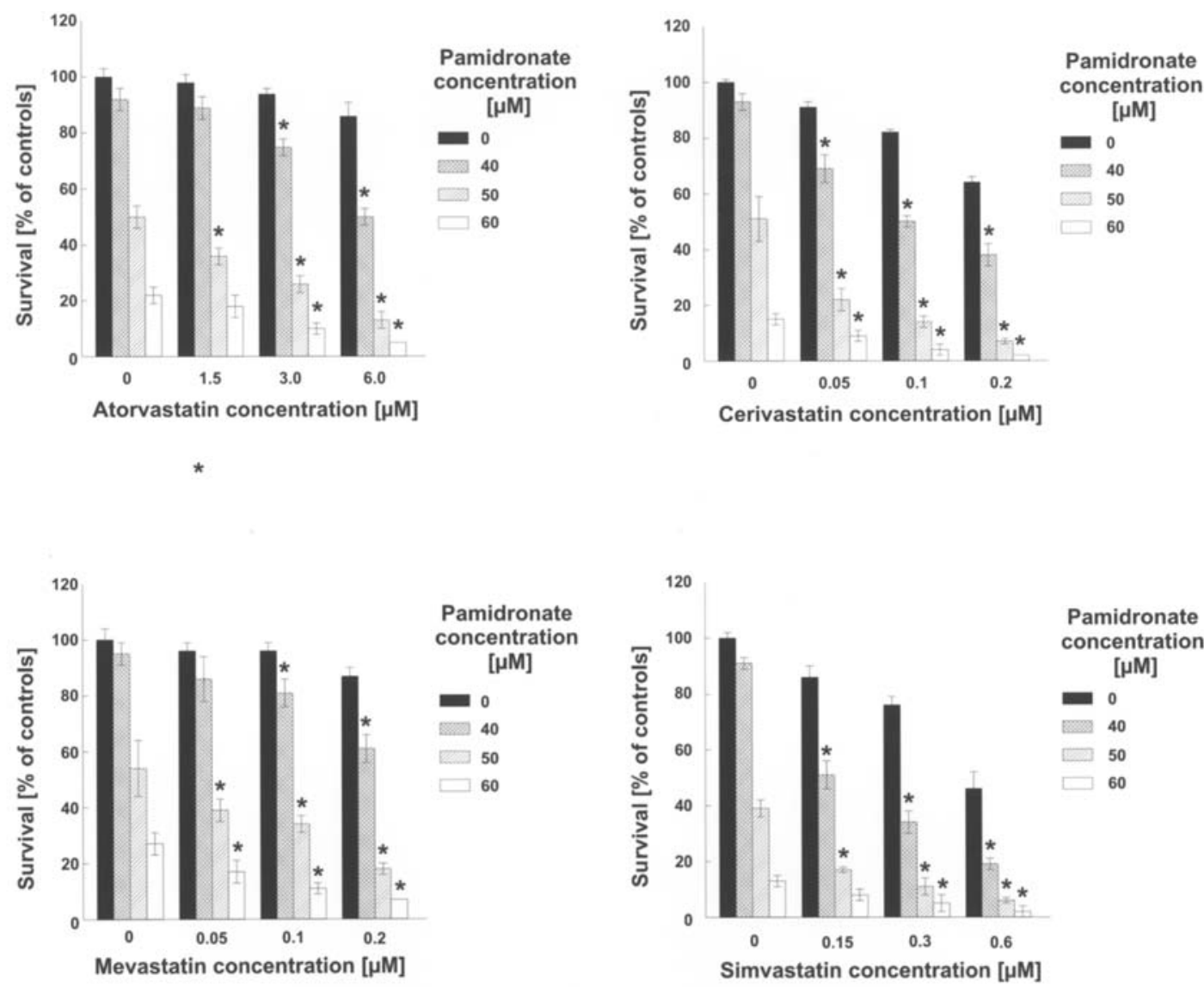

Figure 2. Potentiation of in vitro cytotoxic effects of pamidronate by statins. PANC 02 cells were dispensed into a 96-well flat-bottomed microtiter plate at a concentration of $5 \times 10^{3}$ cells $/ 100 \mu 1 /$ well. Cells were incubated with dilutions of pamidronate and/or atorvastatin, cerivastatin, mevastatin or simvastatin or a control Et-OH-containing medium. After $48 \mathrm{~h}$ the cytostatic/cytotoxic effects were measured after crystal violet staining and are expressed as mean survival (as compared with controls) \pm S.D. ${ }^{*} \mathrm{P}<0.05$ (Student's t-test) as compared with controls and single agent-treated cells.

Table II. Effects of pamidronate, lovastatin and drug combination on PANC 02 cell cycle distribution and apoptosis. ${ }^{a}$

\begin{tabular}{lccccccc}
\hline & Controls & Pam 24 h & Pam 48 & Lova 24 h & Lova 48 h & Pam + Lova 24 h & Pam + Lova 48 h \\
\hline \% Sub-G1 & 3.54 & 3.80 & 3.67 & 4.11 & 18.47 & 4.37 & 33.59 \\
\% G1 & 46.13 & 41.28 & 48.95 & 58.16 & 54.68 & 62.39 & 39.57 \\
\% S & 13.61 & 13.46 & 10.11 & 9.74 & 7.25 & 5.97 & 6.15 \\
\% G2/M & 21.73 & 20.72 & 19.92 & 17.94 & 13.21 & 13.75 & 11.53 \\
\hline
\end{tabular}

${ }^{a}$ Cells were grown in Petri dishes for $24 \mathrm{~h}$ before addition of compounds for the indicated time. Pamidronate was used at a $40-\mu \mathrm{M}$ concentration, and lovastatin was used at a $0.25-\mu \mathrm{M}$ concentration. Cell cycle analysis was performed by flow cytometric analysis using ethanol-fixed, propidium iodide-stained cells.

with both pamidronate and lovastatin significantly impaired the capacity of MDA-MB-231 cells to adhere to both fibronectin and collagen IV. After $48 \mathrm{~h}$ of incubation the effects were more pronounced. Incubation of tumor cells with either lovastatin or pamidronate only slightly, but significantly affected adhesion of tumor cells to both proteins. The effects of the combined treatment were more pronounced as they decreased adhesion to fibronectin by $85 \%$ (Fig. $5 \mathrm{E}$ ), and adhesion to collagen IV by $88 \%$ as compared with controls (Fig. 5F).
Migratory capacity of MDA-MB-231 cells was evaluated in a scratch-wound assay. Lovastatin $(0.2 \mu \mathrm{M})$ and pamidronate $(10 \mu \mathrm{M})$ were used at very low concentrations that did not affect cell survival (Fig. 5H). While lovastatin and pamidronate alone inhibited the distance of tumor cell migration by 15.5 and $25 \%$ after $26 \mathrm{~h}$ of assay, the combination treatment inhibited the migratory capacity of MDA-MB-231 cells by $59.5 \%$. After another $24 \mathrm{~h}$ the effects were even more pronounced as lovastatin inhibited tumor cell migration by $25.8 \%$, pamidronate by $43.5 \%$ and the combination by almost $75 \%$ (Fig. $5 \mathrm{G}$ ). As 
A

$24 \mathrm{~h}$
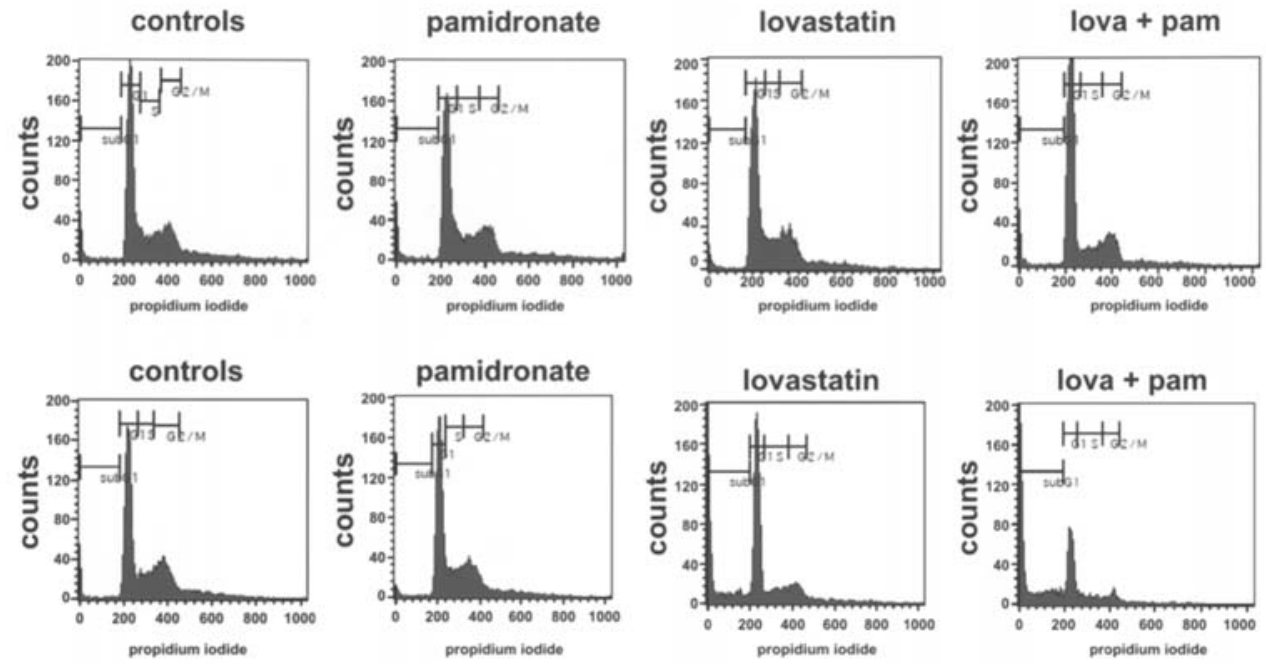

B
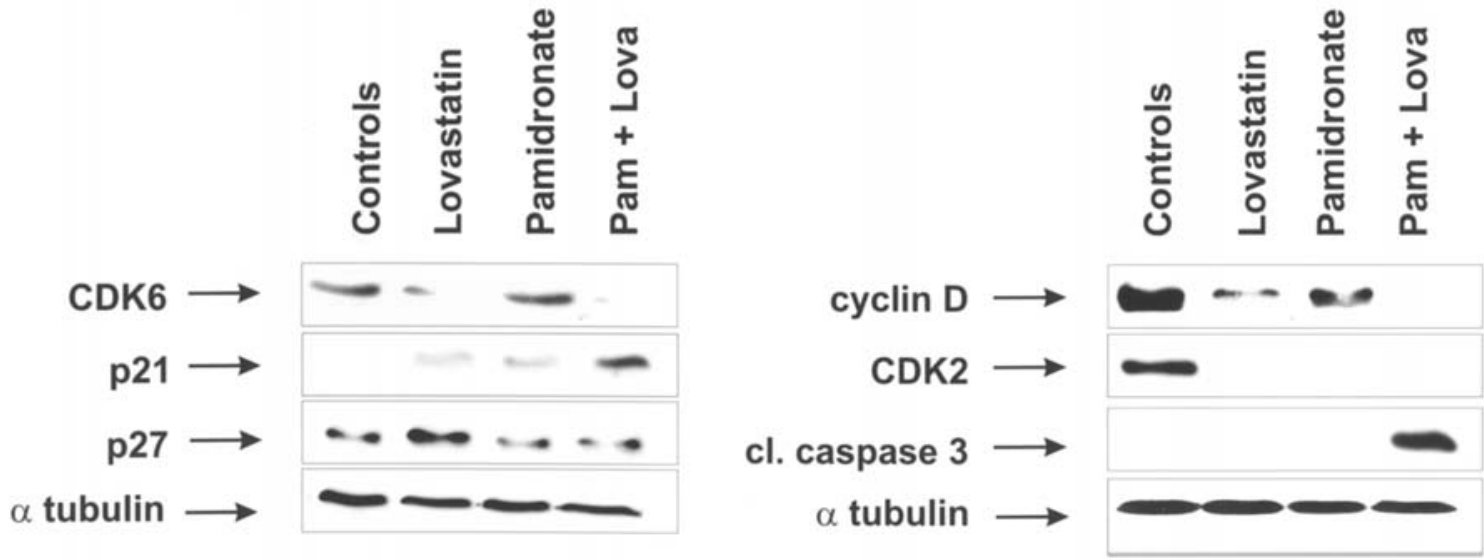

Figure 3. The influence of pamidronate and/or lovastatin on the cell cycle and expression of positive and negative cell cycle regulators as well as cleavage of caspase-3. A, cells were grown in Petri dishes for $24 \mathrm{~h}$ before addition of compounds for the indicated time. Pamidronate was used at a $40-\mu \mathrm{M}$ concentration, and lovastatin was used at a $0.25-\mu \mathrm{M}$ concentration. Cell cycle analysis was performed by flow cytometric analysis using ethanol-fixed, propidium iodidestained cells. B, PANC 02 cells were dispensed into $10-\mathrm{cm}$ Petri dishes at a concentration of $5 \times 10^{5}$ cells $/ 10 \mathrm{ml}$. The cells were cultured in the presence of $0.25-\mu \mathrm{M}$ lovastatin and $40-\mu \mathrm{M}$ pamidronate for $48 \mathrm{~h}$. The cells were harvested and the prepared cell lysates were subjected to Western blot analysis: $50 \mu \mathrm{g}$ of protein extracts were separated during electrophoresis. Blots were sequentially probed (after stripping) with different antibodies.

expected, addition of FPP $(10 \mu \mathrm{M})$ or GGPP $(10 \mu \mathrm{M})$ reversed the inhibition of cell migration (Fig. 5G).

We have also observed a significant inhibition of MDAMB-231 cell invasiveness through the Matrigel extracellular matrix layer by the combination of lovastatin and pamidronate at the concentrations identical as in scratch-wound assay. This effect was superior to the inhibition of invasiveness observed in single agent-treated cells (Fig. 5I and J). As expected, addition of FPP or GGPP partially reversed the inhibitory effect. Since the migration of cells in the Matrigelbased assay is at least partially dependent on extracellular matrix breakdown by secreted metalloproteinases, we have investigated the level of MMP2 and MMP9 gelatinases in cell culture medium. Impaired invasiveness of MDA-MB231 cells was not accompanied by decreased secretion of MMP2 nor MMP9 metaloproteinases to cell culture medium as assayed by gelatin zymography (Fig. 5K).
The combination of pamidronate and lovastatin potentiates antitumor effects in vivo. Next, we decided to evaluate the antitumor activity of the combination treatment in vivo in a murine model of syngeneic pancreatic carcinoma (PANC 02), growing in C57/B16 mice. Treatment with pamidronate and/or lovastatin was started 7 days following inoculation of tumor cells. Pamidronate and lovastatin were administered i.p. at 10 and $30 \mathrm{mg} / \mathrm{kg}$, respectively. Pamidronate was administered twice on days 7 and 14 after inoculation of tumor cells, and lovastatin was administered daily on days 7-21. Although neither of the drugs inhibited tumor growth when given alone, their concomitant administration resulted in both inhibition of tumor growth and prolongation of mouse survival time (Fig. 6). A statistically significant retardation of tumor growth was observed on days 23-42 following inoculation of tumor growth $(\mathrm{P}<0.05$, Student's t-test, as compared with all other groups). The median survival in the combination-treated mice 

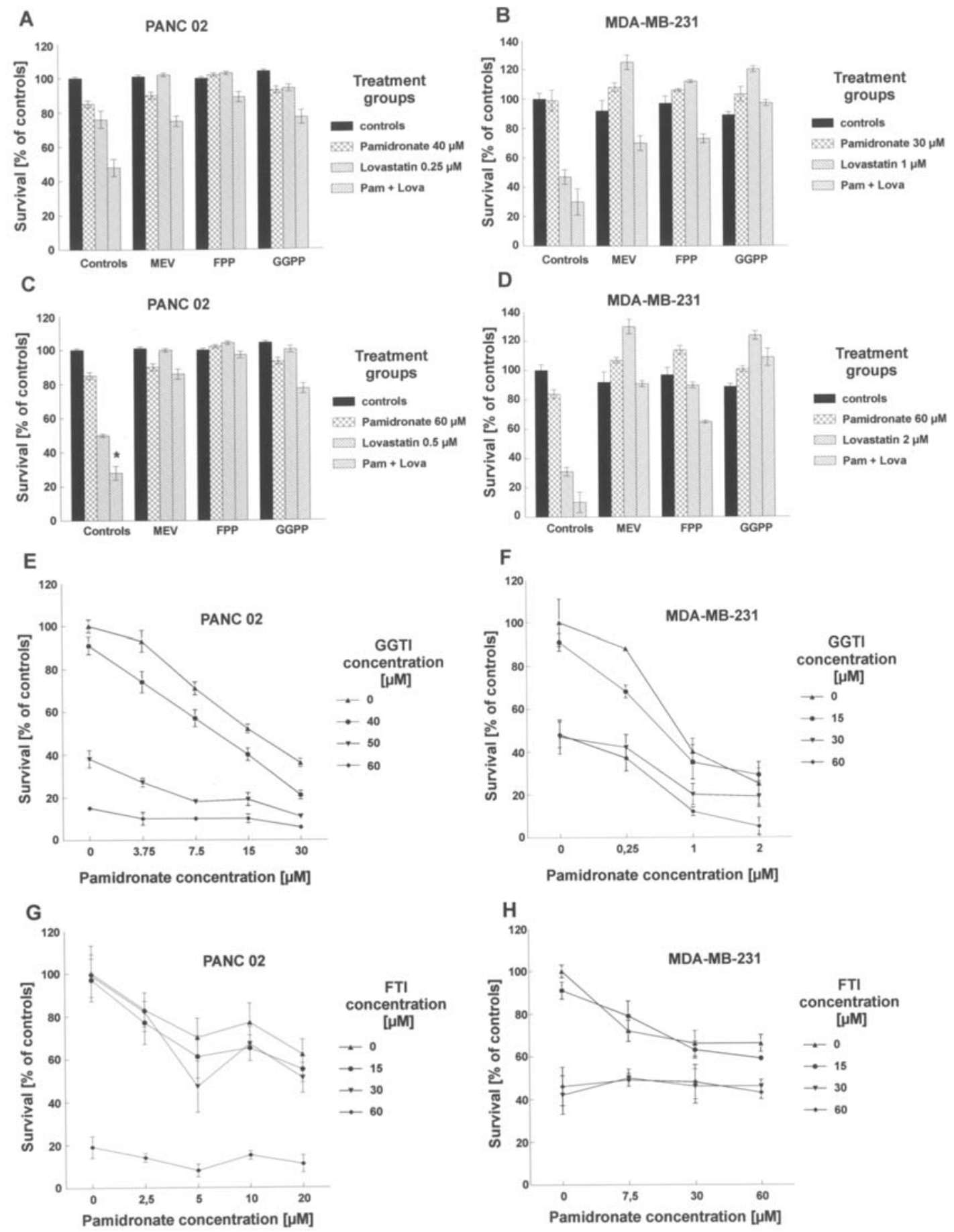

Figure 4. Cytostatic/cytotoxic effects of pamidronate and lovastatin depend on inhibition of protein prenylation. PANC 02 and MDA-MB-231 cells were dispensed into a 96-well flat-bottomed microtiter plate at a concentration of $5 \times 10^{3}$ cells $/ 100 \mu 1 /$ well. (A-D) Cells were incubated with dilutions of pamidronate and/or lovastatin with or without the following precursors of prenyl groups: $200 \mu \mathrm{M}$ mevalonic acid (MEV), $10 \mu \mathrm{M}$ farnesylpyrophosphate (FPP) or $10 \mu \mathrm{M}$ geranylgeranyl pyrophosphate (GGPP). (E-F) Cytostatic/cytotoxic effects of the combinations of pamidronate with geranylgeranyl transferase (GGTI) or farnesyltransferase (FTI) inhibitors. After $48 \mathrm{~h}$ of incubation with drugs the cytostatic/cytotoxic effects were measured using crystal violet staining and are expressed as mean survival (as compared with controls) \pm SD.

(74.5 days) was significantly longer than controls ( 46.5 days), pamidronate (42.5 days) or lovastatin-treated (50.4 days) mice ( $\mathrm{P}<0.05$, log-rank test, as compared with all other groups).

\section{Discussion}

Studies on combined application of HMG-CoA reductase inhibitors and antitumor drugs deserve particular attention as many cancer patients, because of their age, are treated not only with chemotherapeutics but also with statins for accompanying cardiovascular disorders. In most studies on the anti-proliferative and antitumor effects of statins, both in experimental murine models and in humans, lovastatin has been used although atorvastatin, fluvastatin, cerivastatin, simvastatin and pravastatin have also shown antitumor effects (4,44-46). Since the concentrations of statins required for 
Fibronectin
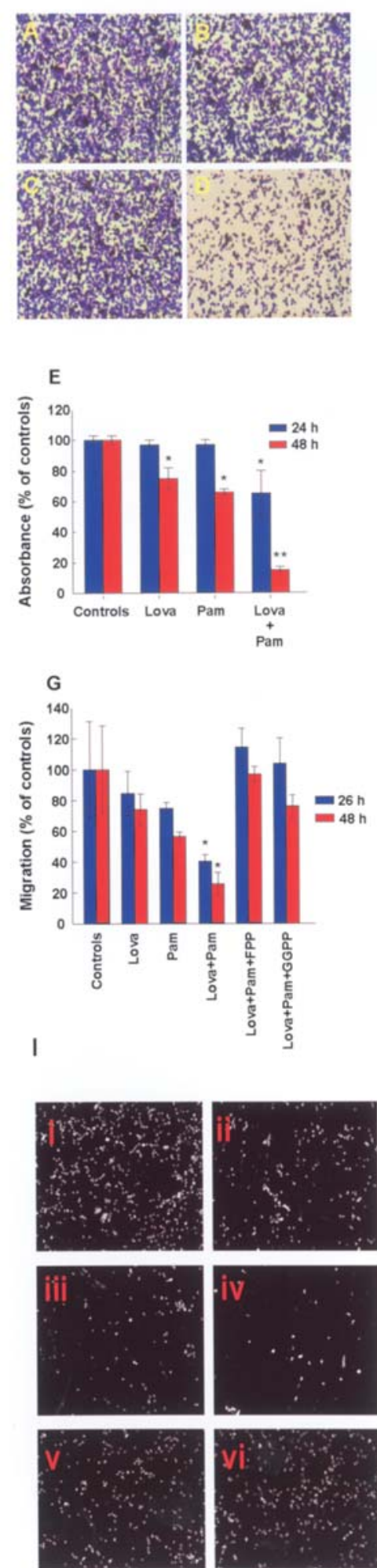
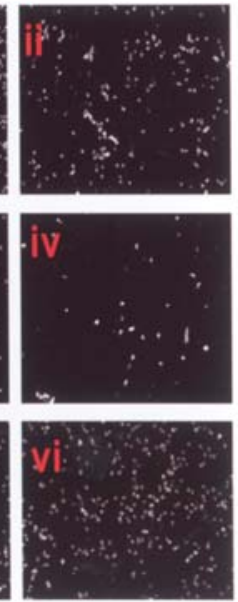

\section{Collagen IV}
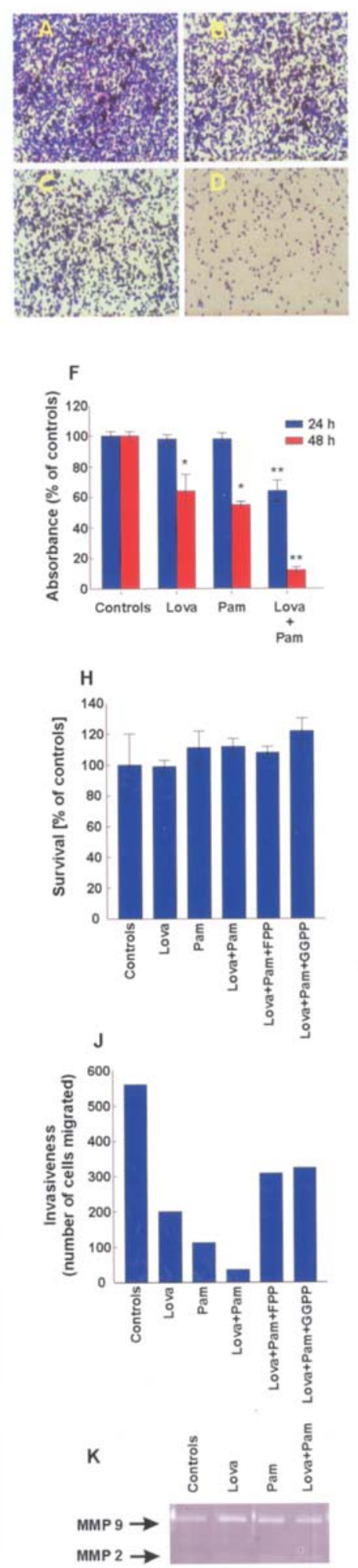

Figure 5. Inhibition of adhesion, migration and invasiveness of tumor cells by the combination of pamidronate and lovastatin. For the adhesion assay MDA-MB-231 cells were incubated with pamidronate $(20 \mu \mathrm{M})$ and/or lovastatin $(0.25 \mu \mathrm{M})$ for 24 or 48 h. Upper part (A-D) shows images of drug-treated crystal violet-stained cells that adhered to either fibronectin or collagen after a 30 -min incubation at $37^{\circ} \mathrm{C}_{\text {in }} \mathrm{CO}^{2}$ incubator. The treatment groups are: $\mathrm{A}$, controls; B, pamidronate; C, lovastatin; D, pamidronate with lovastatin. (E and F) Quantitative assessments of adhesion (\% absorbance as compared with controls) after staining with crystal violet. For the migration $(\mathrm{G})$ and invasion (I and $\mathrm{J}$ ) assays MDA-MB-231 cells were incubated with pamidronate (10 $\mu \mathrm{M}$ ) and/or lovastatin $(0.2 \mu \mathrm{M})$ for 24 or $48 \mathrm{~h}$. (G) Migration of MDA-MB-231 cells was investigated using a scratch-wound assay. The migration of the drugtreated cell population was quantified by calculating the percentage of re-colonization of the wound surface over time as compared with controls. (H) The cytostatic/cytotoxic effects of pamidronate $(10 \mu \mathrm{M})$ and/or lovastatin $(0.2 \mu \mathrm{M})$ either alone or in combination or with FPP $(10 \mu \mathrm{M})$ or GGPP $(10 \mu \mathrm{M})$ against MDA-MB-231 cells measured by crystal violet assay. (I and J) Matrigel invasion assay: i, untreated controls; ii, Lovastatin-treated cells; iii, pamidronatetreated cells; iv, lovastatin + pamidronate-treated cells; v, lovastatin + pamidronate + FPP-treated cells; vi, lovastatin + pamidronate + GGPP-treated cells (K) Gelatin zymography for the detection of MMP2 and MMP9 in supernatants of MDA-MB-231 cells incubated with $0.2 \mu \mathrm{M}$ lovastatin and/or $10 \mu \mathrm{M}$ pamidronate for $48 \mathrm{~h}$. All experiments were performed at least twice with comparable differences between experimental groups. ${ }^{*} \mathrm{P}<0.05$ (Student's t-test) in comparison with controls, ${ }^{* *} \mathrm{P}<0.05$ (Student's t-test) in comparison with all other groups. 
A

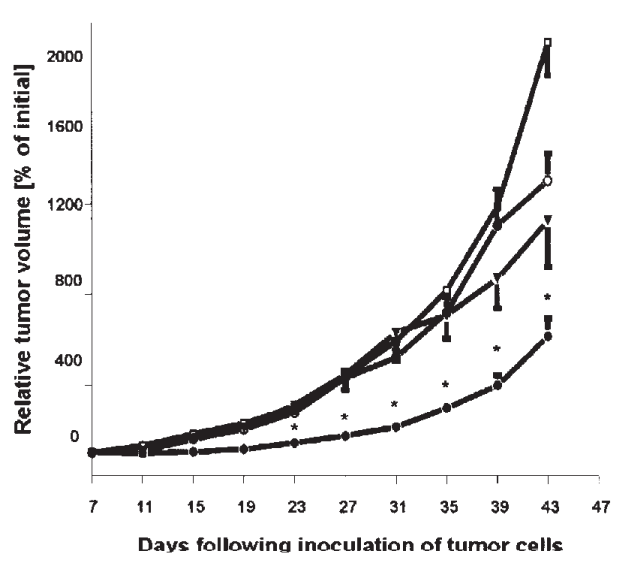

B

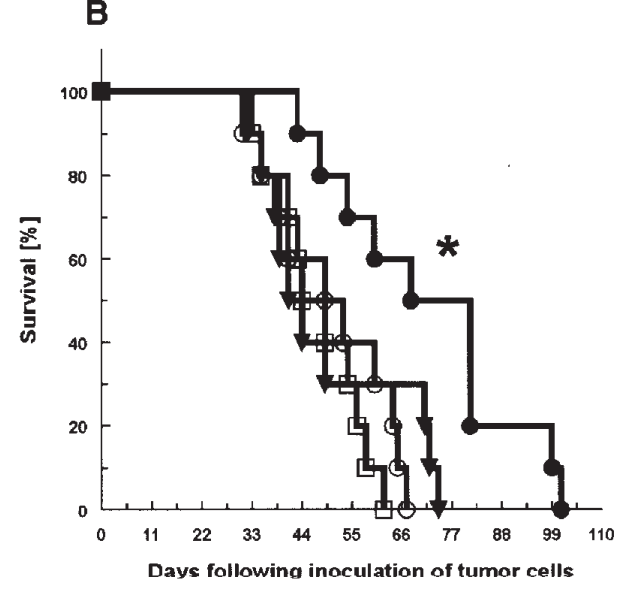

Figure 6. Antitumor effect of the combined treatment with pamidronate and/or lovastatin in PANC 02-bearing mice. C57/B16 mice were inoculated with $2 \times 10^{5}$ PANC 02 cells. Administration of lovastatin $(30 \mathrm{mg} / \mathrm{kg})$ was started on day 7 and continued for 2 consecutive weeks. Pamidronate was administered twice at a dose of $10 \mathrm{mg} / \mathrm{kg}$ on days 7 and 14 following inoculation of tumor cells. (A) The influence of the treatment on the growth of PANC 02 tumors in mice. ${ }^{*} \mathrm{P}<0.05$ (Student's t-test) in comparison with all other groups. (B) Kaplan-Meier plots of the survival of the PANC 02 -bearing mice. ${ }^{*} \mathrm{P}<0.05$ (log-rank test) in comparison with all other groups. There were 10 mice in each experimental group.

antiproliferative effects and especially for the induction of apoptosis in vitro are frequently far from those achievable in vivo, and both in experimental tumor models and in clinical trials statins exert only modest antitumor effects it can be hypothesized that these drugs should be used in combination with other agents. In our studies we have used statin concentrations that are readily achievable in plasma after oral administration. In the lipid-lowering regimens, the peak plasma concentration of lovastatin was in the range of 0.1-3.9 $\mu \mathrm{M}$ (10). However, in a recent clinical study with lovastatin taken by patients with advanced malignancies the peak plasma concentration reached $12.3 \mu \mathrm{M}$ (47).

In one of the recent studies a series of drugs including carboplatin, cisplatin, 5-fluorouracil, docetaxel, epirubicin, fluvastatin, gemcitabine, imatinib, paclitaxel, trastuzumab, or vinorelbine were studied in vitro in combination with zoledronic acid (48). Interestingly, one of the drugs that significantly potentiated the antiproliferative effectiveness of zoledronic acid was fluvastatin. Therefore, our studies confirm that statins can effectively potentiate the cytostatic/cytotoxic effects of bisphosphonates and extend these observations by showing that the combination is also effective in inhibiting invasiveness of tumor cells. Moreover, we show here for the first time that lovastatin in combination with pamidronate is also effective in vivo in both retarding tumor growth and in prolonging the survival of tumor-bearing mice.

The combination of statins used with BPs has several potential benefits and therefore holds promise for clinical development. Both groups of drugs have a good safety profile and can be administered without significant toxicity for a long term $(49,50)$. Although they seem to have a different mechanism of action both classes of these drugs target posttranslational prenylation of proteins. Bisphosphonates, including pamidronate have been shown to effectively inhibit Farnesyl pyrophosphate synthase, and posttranslational prenylation of Ras or Rap1A proteins (51-53). Although statins which inhibit synthesis of mevalonic acid prevent both farnesylation and geranylgeranylation of selected proteins, their mechanism of antiproliferative, cytotoxic and anti-invasive effects is usually ascribed to impaired geranylgeranylation. Usually GGPP, but not FPP, prevents most of the statininduced effects in tumor and normal cells (54-56). It has recently been reported that $\mathrm{R} 115777$, a farnesyltransferase inhibitor, synergistically potentiates cytostatic and proapoptotic effects of BPs in vitro (57). Our studies confirm the observation that drugs that interfere with protein prenylation are effective in potentiating antitumor effects of BPs in vitro and we extend this observation to an in vivo model in experimental mice, where the combination treatment produced both retardation of tumor growth as well as prolonged survival. Moreover, we observed that although some cells (MDA-MB-231) might be resistant to the cytostatic effects of the combination of FTI and pamidronate (Fig. $4 \mathrm{H}$ ) they are sensitive to the combination of pamidronate with statins (Fig. 1) and GGTI (Fig. 4E-F). While the mechanisms of this interaction have not been elucidated in detail it can be hypothesized that pamidronate exerts its effects by inhibiting protein farnesylation while statins additionally target protein geranylgeranylation. Indeed, it was previously reported that GGTase I inhibitors synergize with FTase inhibitors in inducing cytostatic/cytotoxic effects against tumor cells (58-60). Unexpectedly, we have also observed that pamidronate significantly decreased the cytostatic/cytotoxic effects of lovastatin against MCF7 cells. The mechanism of this antagonism is not readily understood. One likely explanation for this phenomenon is that MCF7 cells carry an inactivating mutation within the caspase- 3 gene (61) and as shown in Fig. 4 the combination of pamidronate and lovastatin induces pronounced cleavage and activation of this apoptosis executioner. It will be very interesting to investigate whether lack of caspase- 3 is responsible for the resistance to this combination treatment.

The combination of lovastatin and pamidronate produced G1 cell cycle arrest within $24 \mathrm{~h}$ of incubation with drugs, followed by the transition of G1-arrested cells into sub-G1 fraction. This observation together with effective activation of caspase- 3 in the combination group indicates that the drugs induce initial cell cycle arrest followed by induction of apoptosis. 
Clinically BPs are especially effective in inhibiting bone metastases of tumor cells but several animal studies have also reported inhibition of metastases to soft tissues (17). Therefore, of special importance is effective potentiation of anti-invasive properties of pamidronate by lovastatin. Importantly, these effects were observed at low drug doses that can be easily achieved in cancer patients. In the adhesion, scratch-wound and Matrigel-invasion assays we have used minimal lovastatin and pamidronate concentrations that did not affect cell number in crystal violet assay (Fig. 5H). These small concentrations of both drugs efficiently inhibited three crucial steps in the formation of cancer metastases. Although both bisphosphonates and statins have been shown to decrease the synthesis of matrix metalloproteinases by tumor and stromal cells (62-65) we did not observe any influence of low doses of drugs on the MMP2 and MMP9 activity in supernatants from either single agent- or combination-treated cells (Fig. 5K). These results indirectly indicate that decreased invasiveness of tumor cells results from impaired adhesion/migration (both regulated by Rho family proteins) and not from impaired degradation of ECM proteins. Again, FPP and GGPP strongly reversed the effects of the combination treatment thereby providing further support for the hypothesis that statins and pamidronate mainly target protein prenylation. Indeed a number of other studies revealed that both statins and bisphosphonates inhibit the adhesion, migration and invasiveness of tumor cells by impaired farnesylation and/or geranylgeranylation.

Perhaps the most significant finding of the current report is that the combination of pamidronate and lovastatin exhibited marked antitumor effects in vivo, despite negligible effects observed in single agent-treated mice. These results are of immediate translational importance as statins have also been shown to inhibit copious production of proinflammatory cytokines by peripheral blood $\gamma \delta \mathrm{T}$ cells in response to BPs thereby offering a means of avoiding the BP-associated acute phase response (66).

Altogether we have observed that the combination of statins and pamidronate, a second generation BP, is effective in potentiating cytostatic/cytotoxic effects in vitro, inhibition of adhesion, migration and invasiveness of tumor cells and in exerting antitumor effects in an in vivo tumor model. Together with the reported statin-mediated reduction of bisphosphonateinduced acute phase response this combination holds promise for future clinical studies.

\section{Acknowledgements}

We would like to thank Anna Czerepinska and Elzbieta Gutowska for excellent technical assistance and Dr Wojciech Feleszko for help with statistical analyses. Marcin Makowski is a recipient of the Foundation for Polish Science Award.

\section{References}

1. Tobert JA: Lovastatin and beyond: the history of the HMG-CoA reductase inhibitors. Nat Rev Drug Discov 2: 517-526, 2003.

2. Jakobisiak M, Bruno S, Skierski JS and Darzynkiewicz Z: Cell cycle-specific effects of lovastatin. Proc Natl Acad Sci USA 88: 3628-3632, 1991 .

3. Keyomarsi K, Sandoval L, Band V and Pardee AB: Synchronization of tumor and normal cells from G1 to multiple cell cycles by lovastatin. Cancer Res 51: 3602-3609, 1991.
4. Giermasz A, Makowski M, Kozlowska E, Nowis D, Maj M, Jalili A, Feleszko W, Wojcik C, Dabrowska A, Jakobisiak M and Golab J: Potentiating antitumor effects of a combination therapy with lovastatin and butyrate in the Lewis lung carcinoma model in mice. Int J Cancer 97: 746-750, 2002.

5. Alonso DF, Farina HG, Skilton G, Gabri MR, De Lorenzo MS and Gomez DE: Reduction of mouse mammary tumor formation and metastasis by lovastatin, an inhibitor of the mevalonate pathway of cholesterol synthesis. Breast Cancer Res Treat 50: 83-93, 1998.

6. Matar P, Rozados VR, Binda MM, Roggero EA, Bonfil RD and Scharovsky OG: Inhibitory effect of Lovastatin on spontaneous metastases derived from a rat lymphoma. Clin Exp Metastasis 17: 19-25, 1999

7. Soma MR, Baetta R, De Renzis MR, Mazzini G, Davegna C, Magrassi L, Butti G, Pezzotta S, Paoletti R and Fumagalli R: In vivo enhanced antitumor activity of carmustine [N,N'-bis(2chloroethyl)-N-nitrosourea] by simvastatin. Cancer Res 55: 597-602, 1995.

8. Jani JP, Specht S, Stemmler N, Blanock K, Singh SV, Gupta V and Katoh A: Metastasis of B16F10 mouse melanoma inhibited by lovastatin, an inhibitor of cholesterol biosynthesis. Invasion Metastasis 13: 314-324, 1993.

9. Kawata S, Yamasaki E, Nagase T, Inui Y, Ito N, Matsuda Y, Inada M, Tamura S, Noda S, Imai Y and Matsuzawa Y: Effect of pravastatin on survival in patients with advanced hepatocellular carcinoma. A randomized controlled trial. Br J Cancer 84: 886-891, 2001.

10. Thibault A, Samid D, Tompkins AC, Figg WD, Cooper MR, Hohl RJ, Trepel J, Liang B, Patronas N, Venzon DJ, Reed E and Myers CE: Phase I study of lovastatin, an inhibitor of the mevalonate pathway, in patients with cancer. Clin Cancer Res 2: 483-491, 1996.

11. Graaf MR, Beiderbeck AB, Egberts AC, Richel DJ and Guchelaar HJ: The risk of cancer in users of statins. J Clin Oncol 22: 2388-2394, 2004.

12. Poynter JN, Gruber SB, Higgins PD, Almog R, Bonner JD, Rennert HS, Low M, Greenson JK and Rennert G: Statins and the risk of colorectal cancer. N Engl J Med 352: 2184-2192, 2005.

13. Kaye JA and Jick H: Statin use and cancer risk in the General Practice Research Database. Br J Cancer 90: 635-637, 2004.

14. Bonovas S, Filioussi K, Tsavaris N and Sitaras NM: Use of statins and breast cancer: a meta-analysis of seven randomized clinical trials and nine observational studies. J Clin Oncol 23: 8606-8612, 2005.

15. Coogan PF, Rosenberg L, Palmer JR, Strom BL, Zauber AG and Shapiro S: Statin use and the risk of breast and prostate cancer. Epidemiology 13: 262-267, 2002.

16. Santini D, Vespasiani Gentilucci U, Vincenzi B, Picardi A, Vasaturo F, La Cesa A, Onori N, Scarpa S and Tonini G: The antineoplastic role of bisphosphonates: from basic research to clinical evidence. Ann Oncol 14: 1468-1476, 2003.

17. Coleman RE: Bisphosphonates: clinical experience. Oncologist 9 (suppl 4): 14-27, 2004.

18. Berenson JR, Lichtenstein A, Porter L, Dimopoulos MA, Bordoni R, George S, Lipton A, Keller A, Ballester O, Kovacs MJ, Blacklock HA, Bell R, Simeone J, Reitsma DJ, Heffernan M, Seaman J and Knight RD: Efficacy of pamidronate in reducing skeletal events in patients with advanced multiple myeloma. Myeloma Aredia Study Group. N Engl J Med 334: 488-493, 1996.

19. Hortobagyi GN, Theriault RL, Porter L, Blayney D, Lipton A, Sinoff C, Wheeler H, Simeone JF, Seaman J and Knight RD: Efficacy of pamidronate in reducing skeletal complications in patients with breast cancer and lytic bone metastases. Protocol 19 Aredia Breast Cancer Study Group. N Engl J Med 335: 1785-1791, 1996.

20. Theriault RL, Lipton A, Hortobagyi GN, Leff R, Gluck S, Stewart JF, Costello S, Kennedy I, Simeone J, Seaman JJ, Knight RD, Mellars K, Heffernan $M$ and Reitsma DJ: Pamidronate reduces skeletal morbidity in women with advanced breast cancer and lytic bone lesions: a randomized, placebocontrolled trial. Protocol 18 Aredia Breast Cancer Study Group. J Clin Oncol 17: 846-854, 1999.

21. Fleisch H: Bisphosphonates. Pharmacology and use in the treatment of tumour-induced hypercalcaemic and metastatic bone disease. Drugs 42: 919-944, 1991.

22. Berenson JR: Treatment of hypercalcemia of malignancy with bisphosphonates. Semin Oncol 29: 12-18, 2002. 
23. Dunford JE, Thompson K, Coxon FP, Luckman SP, Hahn FM, Poulter CD, Ebetino FH and Rogers MJ: Structure-activity relationships for inhibition of farnesyl diphosphate synthase in vitro and inhibition of bone resorption in vivo by nitrogencontaining bisphosphonates. J Pharmacol Exp Ther 296: 235-242, 2001.

24. Luckman SP, Hughes DE, Coxon FP, Graham R, Russell G and Rogers MJ: Nitrogen-containing bisphosphonates inhibit the mevalonate pathway and prevent post-translational prenylation of GTP-binding proteins, including Ras. J Bone Miner Res 13: 581-589, 1998

25. Clezardin P, Ebetino FH and Fournier PG: Bisphosphonates and cancer-induced bone disease: beyond their antiresorptive activity. Cancer Res 65: 4971-4974, 2005.

26. Corey E, Brown LG, Quinn JE, Poot M, Roudier MP, Higano CS and Vessella RL: Zoledronic acid exhibits inhibitory effects on osteoblastic and osteolytic metastases of prostate cancer. Clin Cancer Res 9: 295-306, 2003.

27. Hiraga T, Williams PJ, Ueda A, Tamura D and Yoneda T: Zoledronic acid inhibits visceral metastases in the 4T1/luc mouse breast cancer model. Clin Cancer Res 10: 4559-4567, 2004.

28. Smith MR: Antitumor activity of bisphosphonates. Clin Cancer Res 9: 5433-5434, 2003.

29. Santini D, Vincenzi B, Tonini G, Scarpa S and Baldi A: Zoledronic acid exhibits inhibitory effects on osteoblastic and osteolytic metastases of prostate cancer. Clin Cancer Res 9: 3215; author reply 3216, 2003.

30. Wood J, Bonjean K, Ruetz S, Bellahcene A, Devy L, Foidart JM, Castronovo V and Green JR: Novel antiangiogenic effects of the bisphosphonate compound zoledronic acid. J Pharmacol Exp Ther 302: 1055-1061, 2002.

31. Santini D, Vincenzi B, Dicuonzo G, Avvisati G, Massacesi C, Battistoni F, Gavasci M, Rocci L, Tirindelli MC, Altomare V, Tocchini M, Bonsignori $\mathrm{M}$ and Tonini G: Zoledronic acid induces significant and long-lasting modifications of circulating angiogenic factors in cancer patients. Clin Cancer Res 9: 2893-2897, 2003.

32. Yamagishi S, Abe R, Inagaki Y, Nakamura K, Sugawara H, Inokuma D, Nakamura H, Shimizu T, Takeuchi M, Yoshimura A, Bucala R, Shimizu H and Imaizumi T: Minodronate, a newly developed nitrogen-containing bisphosphonate, suppresses melanoma growth and improves survival in nude mice by blocking vascular endothelial growth factor signaling. Am J Pathol 165: 1865-1874, 2004.

33. Coleman RE: Bisphosphonates in breast cancer. Ann Oncol 16: 687-695, 2005

34. Kohno N, Aogi K, Minami H, Nakamura S, Asaga T, Iino Y, Watanabe T, Goessl C, Ohashi Y and Takashima S: Zoledronic acid significantly reduces skeletal complications compared with placebo in Japanese women with bone metastases from breast cancer: a randomized, placebo-controlled trial. J Clin Oncol 23: 3314-3321, 2005.

35. Yano S, Zhang H, Hanibuchi M, Miki T, Goto H, Uehara H and Sone S: Combined therapy with a new bisphosphonate, minodronate (YM529) and chemotherapy for multiple organ metastases of small cell lung cancer cells in severe combined immunodeficient mice. Clin Cancer Res 9: 5380-5385, 2003.

36. Inoue K, Karashima T, Fukata S, Nomura A, Kawada C, Kurabayashi A, Furihata M, Ohtsuki Y and Shuin T: Effect of combination therapy with a novel bisphosphonate, minodronate (YM529) and docetaxel on a model of bone metastasis by human transitional cell carcinoma. Clin Cancer Res 11: 6669-6677, 2005.

37. Neville-Webbe HL, Rostami-Hodjegan A, Evans CA, Coleman RE and Holen I: Sequence- and schedule-dependent enhancement of zoledronic acid induced apoptosis by doxorubicin in breast and prostate cancer cells. Int J Cancer 113: 364-371, 2005.

38. Algur E, Macklis RM and Hafeli UO: Synergistic cytotoxic effects of zoledronic acid and radiation in human prostate cancer and myeloma cell lines. Int J Radiat Oncol Biol Phys 61: 535-542, 2005.

39. Journe F, Chaboteaux C, Magne N, Duvillier H, Laurent G and Body JJ: Additive growth inhibitory effects of ibandronate and antiestrogens in estrogen receptor-positive breast cancer cell lines. Breast Cancer Res 8: R2, 2005.

40. Feleszko W, Zagozdzon R, Golab J and Jakobisiak M: Potentiated antitumour effects of cisplatin and lovastatin against MmB16 melanoma in mice. Eur J Cancer 34: 406-411, 1998.
41. Golab J, Stoklosa T, Zagozdzon R, Kaca A, Giermasz A, Pojda Z, Machaj E, Dabrowska A, Feleszko W, Lasek W, Iwan-Osiecka A and Jakobisiak M: G-CSF prevents the suppression of bone marrow hematopoiesis induced by IL-12 and augments its anti-tumor activity in a melanoma model in mice. Ann Oncol 9: 63-69, 1998.

42. Nowis D, Legat M, Grzela T, Niderla J, Wilczek E, Wilczynski GM, Glodkowska E, Mrowka P, Issat T, Dulak J, Jozkowicz A, Was H, Adamek M, Wrzosek A, Nazarewski S, Makowski M, Stoklosa T, Jakobisiak M and Golab J: Heme oxygenase-1 protects tumor cells against photodynamic therapymediated cytotoxicity. Oncogene 25: 3365-3374, 2006.

43. Chou TC and Talalay P: Quantitative analysis of dose-effect relationships: the combined effects of multiple drugs or enzyme inhibitors. Adv Enzyme Regul 22: 27-55, 1984.

44. Jakobisiak M and Golab J: Potential antitumor effects of statins (Review). Int J Oncol 23: 1055-1069, 2003.

45. Kozar K, Kaminski R, Legat M, Kopec M, Nowis D, Skierski JS, Koronkiewicz M, Jakobisiak M and Golab J: Cerivastatin demonstrates enhanced antitumor activity against human breast cancer cell lines when used in combination with doxorubicin or cisplatin. Int J Oncol 24: 1149-1157, 2004.

46. Kozar K, Kaminski R, Switaj T, Oldak T, Machaj E, Wysocki PJ, Mackiewicz A, Lasek W, Jakobisiak M and Golab J: Interleukin 12-based immunotherapy improves the antitumor effectiveness of a low-dose 5-Aza-2'-deoxycitidine treatment in L1210 leukemia and B16F10 melanoma models in mice. Clin Cancer Res 9: 3124-3133, 2003.

47. Holstein SA, Knapp HR, Clamon GH, Murry DJ and Hohl RJ: Pharmacodynamic effects of high dose lovastatin in subjects with advanced malignancies. Cancer Chemother Pharmacol 57: 155-164, 2006.

48. Budman DR and Calabro A: Zoledronic acid (Zometa) enhances the cytotoxic effect of gemcitabine and fluvastatin: in vitro isobologram studies with conventional and nonconventional cytotoxic agents. Oncology 70: 147-153, 2006.

49. Katz MS: Therapy insight: potential of statins for cancer chemoprevention and therapy. Nat Clin Pract Oncol 2: 82-89, 2005.

50. Waters D: Statins and safety: applying the results of randomized trials to clinical practice. Am J Cardiol 92: 692-695, 2003.

51. Ohtsuka Y, Manabe A, Kawasaki H, Hasegawa D, Zaike Y, Watanabe S, Tanizawa T, Nakahata T and Tsuji K: RASblocking bisphosphonate zoledronic acid inhibits the abnormal proliferation and differentiation of juvenile myelomonocytic leukemia cells in vitro. Blood 106: 3134-3141, 2005.

52. Gordon S, Helfrich MH, Sati HI, Greaves M, Ralston SH, Culligan DJ, Soutar RL and Rogers MJ: Pamidronate causes apoptosis of plasma cells in vivo in patients with multiple myeloma. Br J Haematol 119: 475-483, 2002.

53. Wada A, Fukui K, Sawai Y, Imanaka K, Kiso S, Tamura S, Shimomura I and Hayashi N: Pamidronate induced antiproliferative, apoptotic and anti-migratory effects in hepatocellular carcinoma. J Hepatol 44: 142-150, 2006.

54. Lee J, Lee I, Park C and Kang WK: Lovastatin-induced RhoA modulation and its effect on senescence in prostate cancer cells. Biochem Biophys Res Commun 339: 748-754, 2006.

55. Xia Z, Tan MM, Wong WW, Dimitroulakos J, Minden MD and Penn LZ: Blocking protein geranylgeranylation is essential for lovastatin-induced apoptosis of human acute myeloid leukemia cells. Leukemia 15: 1398-1407, 2001

56. Tanaka T, Tatsuno I, Uchida D, Moroo I, Morio H, Nakamura S, Noguchi Y, Yasuda T, Kitagawa M, Saito Y and Hirai A: Geranylgeranyl-pyrophosphate, an isoprenoid of mevalonate cascade, is a critical compound for rat primary cultured cortical neurons to protect the cell death induced by 3-hydroxy-3methylglutaryl-CoA reductase inhibition. J Neurosci 20: 2852-2859, 2000.

57. Caraglia M, D'Alessandro AM, Marra M, Giuberti G, Vitale G, Viscomi C, Colao A, Prete SD, Tagliaferri P, Tassone P, Budillon A, Venuta S and Abbruzzese A: The farnesyl transferase inhibitor R115777 (Zarnestra) synergistically enhances growth inhibition and apoptosis induced on epidermoid cancer cells by Zoledronic acid (Zometa) and Pamidronate. Oncogene 23: 6900-6913, 2004.

58. Lobell RB, Omer CA, Abrams MT, Bhimnathwala HG, Brucker MJ, Buser CA, Davide JP, De Solms SJ, Dinsmore CJ, Ellis-Hutchings MS, Kral AM, Liu D, Lumma WC, Machotka SV, Rands E, Williams TM, Graham SL, Hartman GD, Oliff AI, Heimbrook DC and Kohl NE: Evaluation of farnesyl:protein transferase and geranylgeranyl:protein transferase inhibitor combinations in preclinical models. Cancer Res 61: 8758-8768, 2001. 
59. Morgan MA, Sebil T, Aydilek E, Peest D, Ganser A and Reuter CW: Combining prenylation inhibitors causes synergistic cytotoxicity, apoptosis and disruption of RAS-to-MAP kinase signalling in multiple myeloma cells. Br J Haematol 130: 912-925, 2005.

60. Morgan MA, Wegner J, Aydilek E, Ganser A and Reuter CW: Synergistic cytotoxic effects in myeloid leukemia cells upon cotreatment with farnesyltransferase and geranylgeranyl transferase-I inhibitors. Leukemia 17: 1508-1520, 2003.

61. Kagawa S, Gu J, Honda T, McDonnell TJ, Swisher SG, Roth JA and Fang B: Deficiency of caspase- 3 in MCF7 cells blocks Baxmediated nuclear fragmentation but not cell death. Clin Cancer Res 7: 1474-1480, 2001

62. Giraudo E, Inoue M and Hanahan D: An amino-bisphosphonate targets MMP-9-expressing macrophages and angiogenesis to impair cervical carcinogenesis. J Clin Invest 114: 623-633, 2004.
63. Leppa S, Saarto T, Vehmanen L, Blomqvist C and Elomaa I: Clodronate treatment influences MMP-2 associated outcome in node positive breast cancer. Breast Cancer Res Treat 90: 117-125, 2005.

64. Thunyakitpisal PD and Chaisuparat R: Simvastatin, an HMGCoA reductase inhibitor, reduced the expression of matrix metalloproteinase-9 (Gelatinase B) in osteoblastic cells and HT1080 fibrosarcoma cells. J Pharmacol Sci 94: 403-409, 2004.

65. Denoyelle C, Albanese P, Uzan G, Hong L, Vannier JP, Soria J and Soria C: Molecular mechanism of the anti-cancer activity of cerivastatin, an inhibitor of HMG-CoA reductase, on aggressive human breast cancer cells. Cell Signal 15: 327-338, 2003.

66. Hewitt RE, Lissina A, Green AE, Slay ES, Price DA and Sewell AK: The bisphosphonate acute phase response: rapid and copious production of proinflammatory cytokines by peripheral blood gd T cells in response to aminobisphosphonates is inhibited by statins. Clin Exp Immunol 139: 101-111, 2005. 